いる至はは古田安ク南公二公

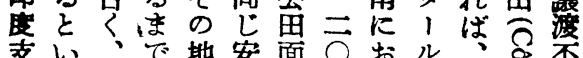

䛍 5 人非理南稳萬いで印品奇

のこ口常的人がへて度安能

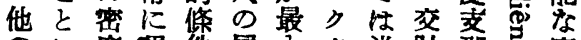

のに庋異件居多夕米跳那定

二留のっだ住ひ1田孛のと期

つ意極てけ方公公那三い割

のしめいたるくの○にう5

邦ててるは以、的萬おの名を

即お高のな上灾三人い安䅌件

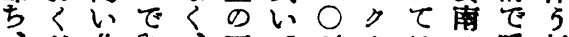
必北め、三で\%夕はの呼村

力要部っ歷つ安を、米邦ん落

厶吕にて更の南占ル田にでの

亦まお、的邦々めの方於い共

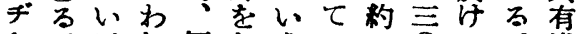

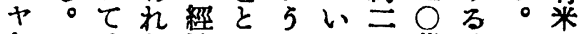

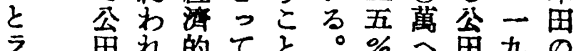

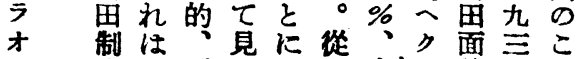

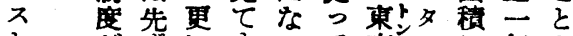

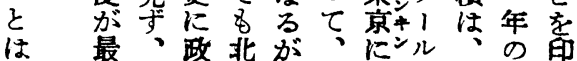

人歷治部、東おの的政度

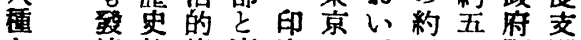

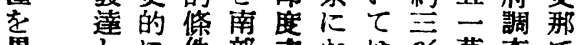

異しに件部夌おは\%萬查で

にて最にと郡け米、へ、は

印

度

支

那

に

to

け

る

公

田

制

分度共及たば郎国にて越なす

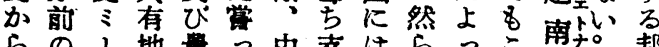

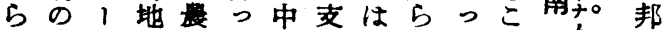
の完儿を業て央郡なばてれのん独で

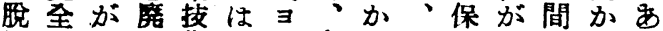

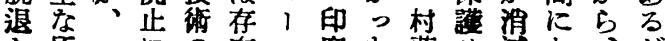
を所一飞の在口度を落せ隇お、が

部有九淮しッ巷らを印

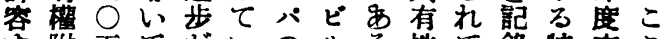
守附五てがいのル万地て錄特菱こ

万讓年い村た國又5 5 來し有郡て |渡|る港。各、吕いたてたは

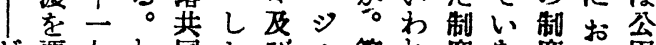

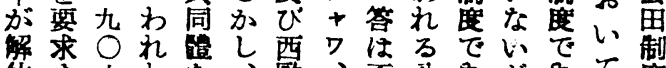
体守六わを、融、否公めど\&て度

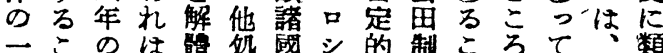

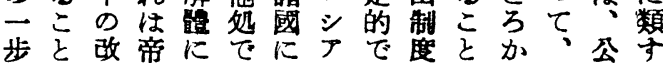
を草政導はお括々が、フ

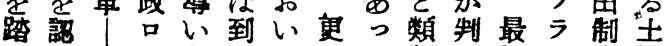

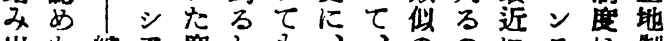
出た總厂度とる、、ののに压制 ᄂ上てに合こ存魔世制で至の安度

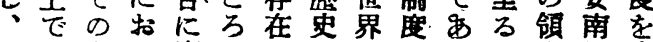

一、曟け應でしをのはるま有民全

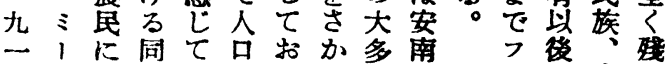

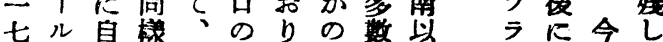

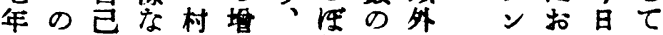
十制の制落加まれ园のス、いの

逸

㫕

重

雄 
織最制にるるはがに はす度よいが孛久準会 安戀のっは、那し无畐 南化中て周々人之七制 民をで支醴のの信創度 族营、那加よ影ぜ殶の 特 5 征化 55 㣦 5 さ歴 有な服さ得な下れれ史 のか者れた學にてた的

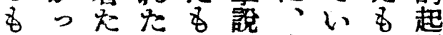
のたる時のは有たの源 で制支代か科史。でに あ度郡方母學以こ周う るは人亦し的前の陑

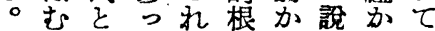
公しのたな㨜らにらは 畐ろ十にいを創よの 制村世はがも設ば影々 度落紀違、たされ蚃れ る組以いまなれ安をが 亦较上なたいて南受家 、てにい安。い國け族 今あ酉加南荗たにたの 日つる、國公こ牧的員 黑て接安加思々けの數 河、解南索なにるだ のこにの那るな村、士 溪のよす人名る落と地 谷村っべの稱の共いの に落てて征はて有5性 住組、の服あ地鿁筫
服5页 へ九民廿たい地月

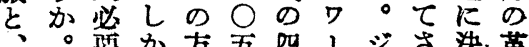
全ことる向年分元十定定

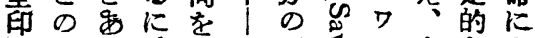
二度興 5 指一三年の十な 卖味ば示九の突住公絡つ

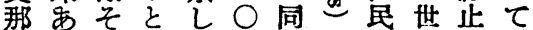
經るのりた六意は村紀符睤 湾間搜印。年を、落末带 の題張度の蘭にの打さ 停は孝夌或つ領打革つれ

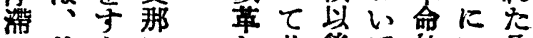
の後らに共後て的い分 理期意扣類有見法た配 にフ㘣い似米村出律つの そラして の田落さがた整 のンたは嘅ののれ村こ致 原不草廃惯る有と各 一甶植こフに步䅦灌地意 を民文ををを溉の想民 求政はンっ謁破さ決起索 め策ど ス らの 5 は れ安し公 る南た田 で伝わ制 \$統计度 ろへでの 万。届要存 てめ期定定 L 公恰志的万。 男多田配フの 制口よ即を与 ミ 度シ 5 ち命ン の厂に共命スル 解の、有合にの

私起ますにま的方年分移落々な制の安をこ賦主れむ

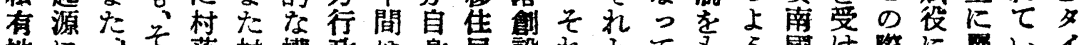

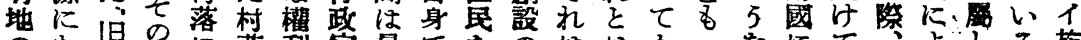

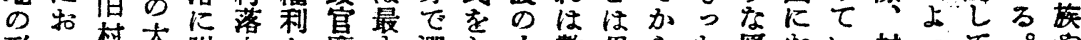

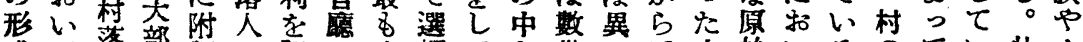

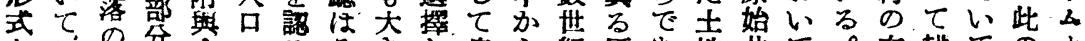
をは領の分ののめそき自ら紀原あ地共て。有耕ての才

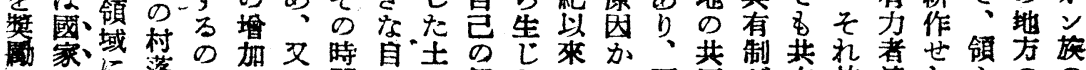
しの再洛でを之開由地好た司而同肪有故達し主のの

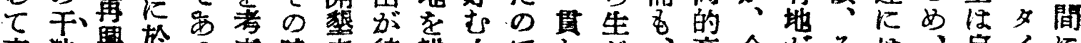

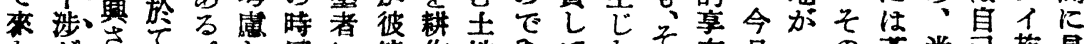

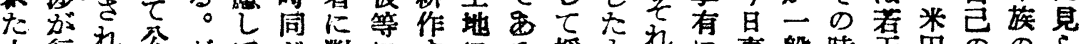

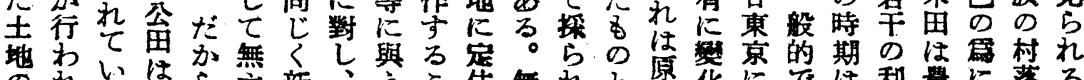

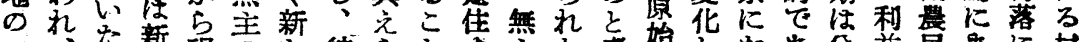

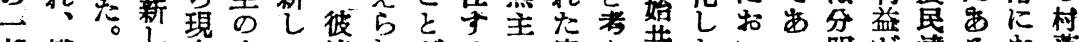

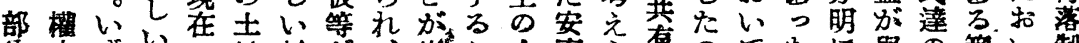

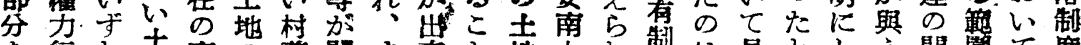

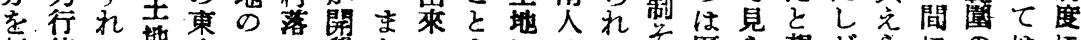

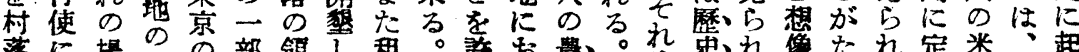

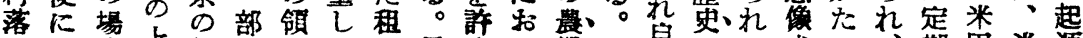
によ合上村分域た程最容い莱、具の、るさい、期田米源

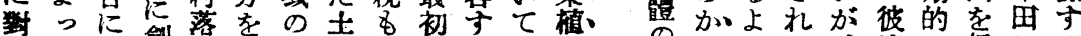

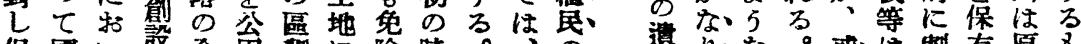
保國以設全畕济に除時。の. 留家て学部のを關劣期人方 しは的热名決子れ等方式。 た最公生な称定るる音民は郎

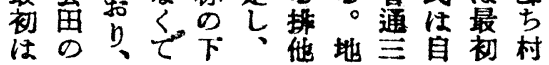

传り、な。或は割有原8 物後定し時、餎撸し䐓の

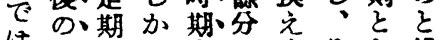

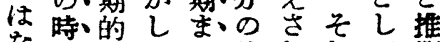
な代製、で分れれて湘 
自略ならににかと力る彼外が望ない加住に、湾は

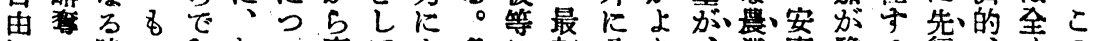
にの時っஇむい值てよ各は初公り業南豫る行、行

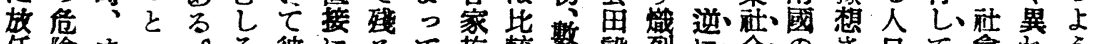

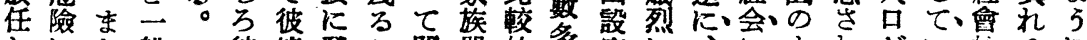

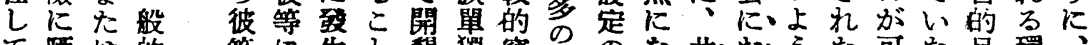
七晒は的 おさ彼に 〈等

なるの公 5 場中画 ば合のが 私艺創 的市設 專るのさ 有。会れ

の共態

運有者の

動制には

がはよ

必加っ住

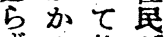
等に生々暞獨 容家

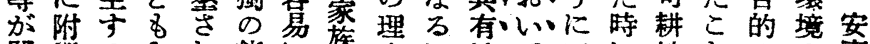

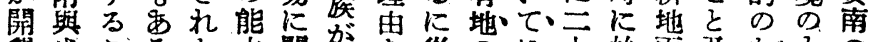

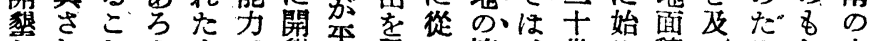

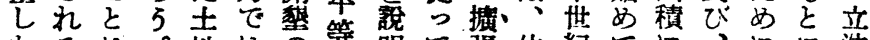
たるは。地はの等明て留、住紀てに、にに法

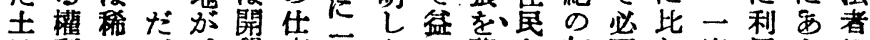

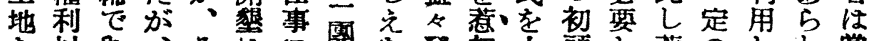
を以す、そはに罗な弡起顗と著のしわ管 泆上る公の筫共末心展し地まなし埸たれて 定に。畕後行同開。したの所。た原 的確ながに出に鮤 に固ぜこ定來從地 分字なの期な事㜂

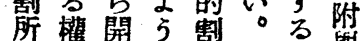

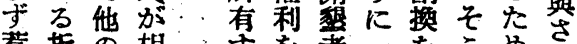
惹折の相、守を者二をこめ斿 起にす互る確は村伴での䚄 す薄に

る若て、協

敵 しの力 路 そ住 やれ尼な る磪は村伴での共の 々有住共各意々

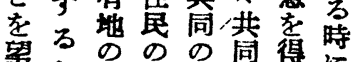
望た分協所の京得に たこ專接菓增にこ二始 のと有、術た大於こ制部 で、のの可して で度会 あ及方進能たははをに るび向步と. 時共、拉 と、に㤎な、同私新い い共引賃っ或的有たて 5 有附・洂たは所地な現 こ地けし。近有がるわ とはるてきは共政れ 此といい將々同治た このいた 来こ的的制 れ願 5、純にに所、度 以望願椊、增定有、䅔 と

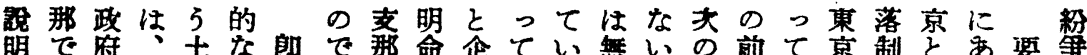

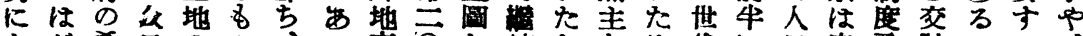
よど希口のの?る方门し螋たなめ代に安度趾のる、

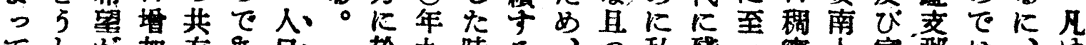

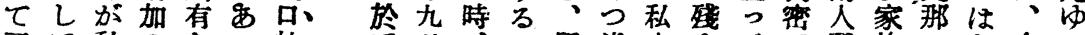
了て私のをつ的宁宁所米有すて發族はな今る

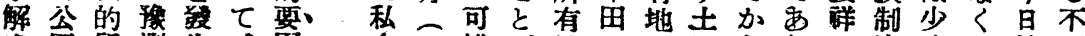

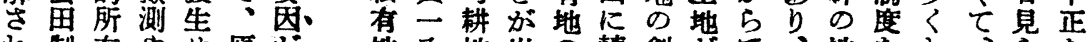
れ制有中世原名 る度に人し始共 で -. 口内共有 北定㙁、同地 ろ部の加国鲩の 5 に限落家に發

。集界惹の於展 中学起形てに し附子成は與 七與る以人宇 いせ紛後口る ろし爭にの謷 加め創塻 之た回設加气 いの避さが 5 でせ定直 理あした期接 由 万村的的 は。ん落㲅县 叙印飞换? 上度与於老決 の支万件定

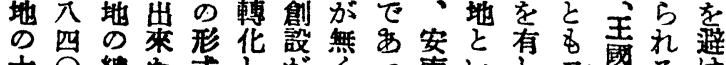

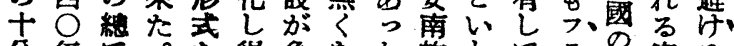
分年て。得急なた族わてラ、の安る

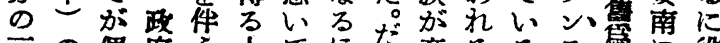

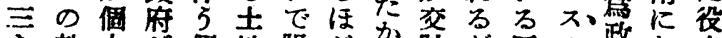

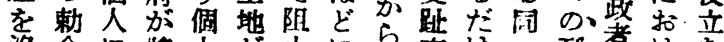
没合に將人怔止にら支汗一到者け市 收はよ來的住さ自吕那西の來原了得

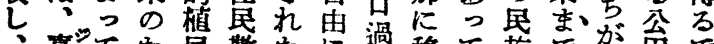

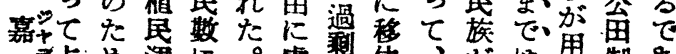
こ定炶め逴に。虎籍住、がは用制か

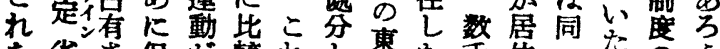

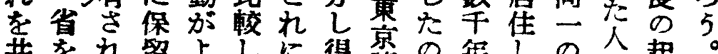

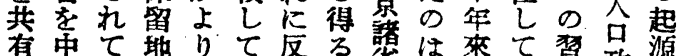
地心W老長多し士省漸安い俗算は にとた設期量交地に年南たと符原

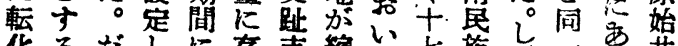

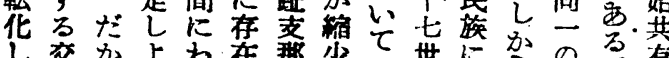

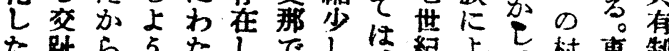




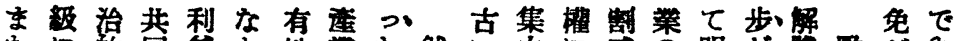

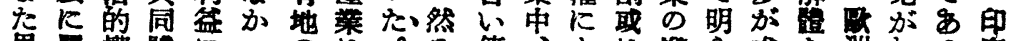

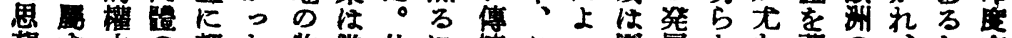

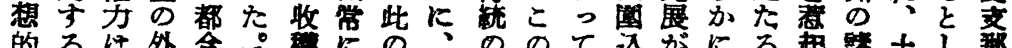

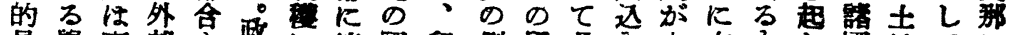

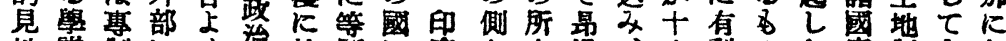

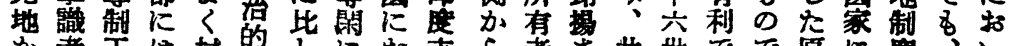
か者王は村盟しに拓夌ら者さ共世でで原に度、い

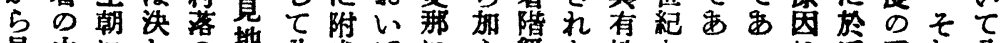

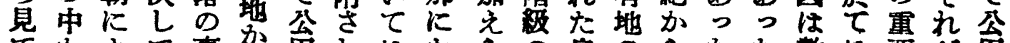

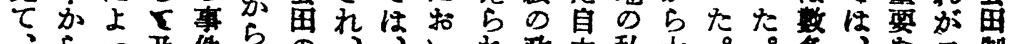

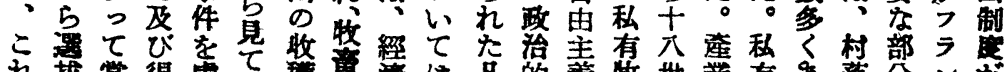

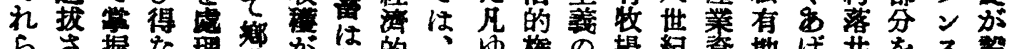

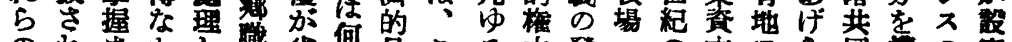

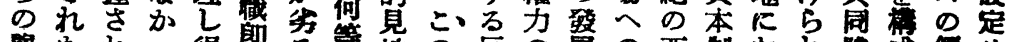

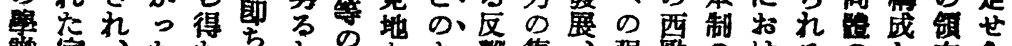

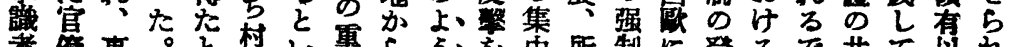

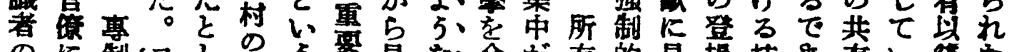

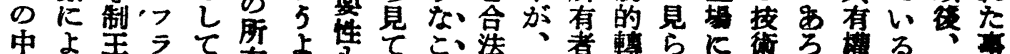

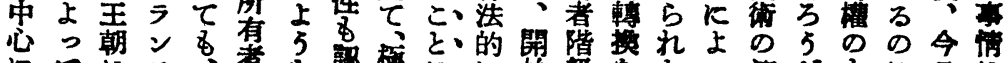

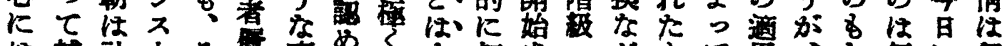

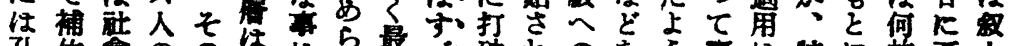

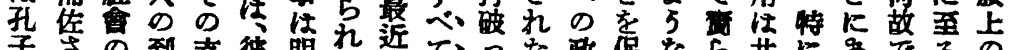

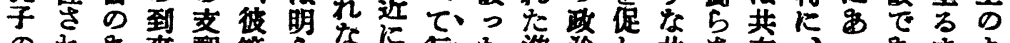

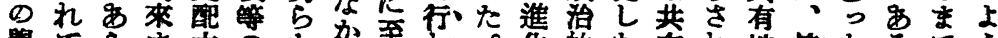

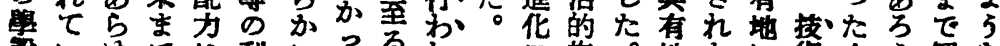

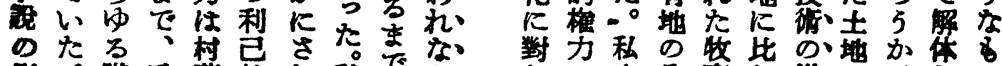

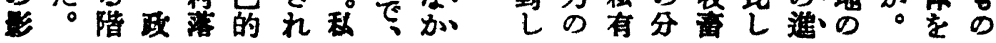

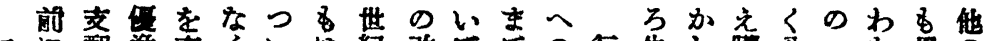

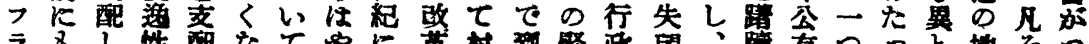

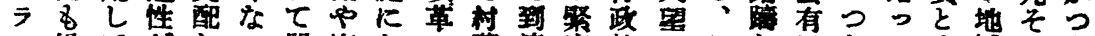

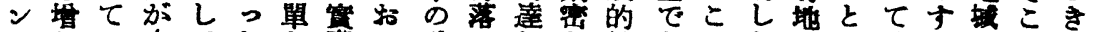

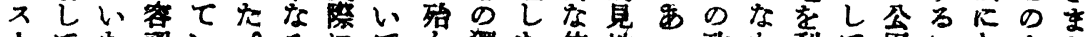

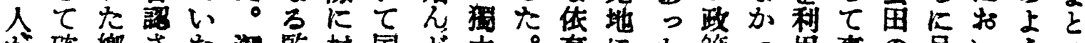

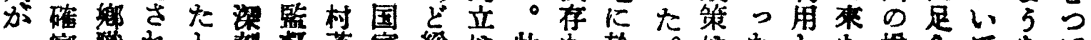

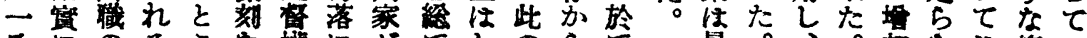

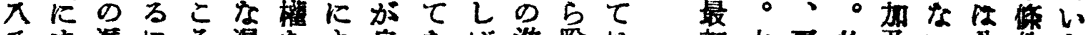

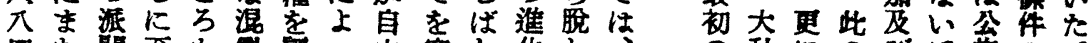

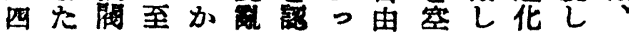
年よをっらをめてに文ばはた村

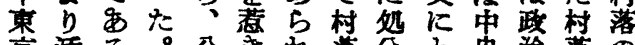

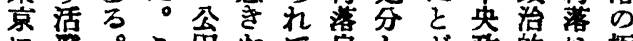

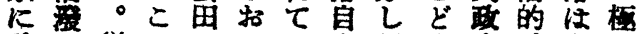
瑟に従このこW身得亦府十力

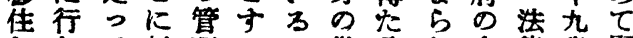
乙わて村理こに世公し企律世揭 てれ、落にと過量画め回的紀著

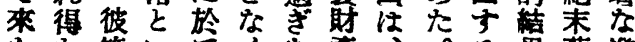

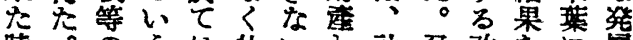

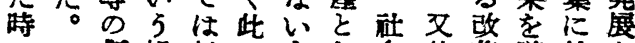

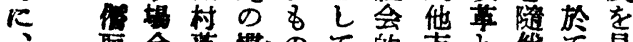
彼聚合落獚のて的方々伴て見 物有肪し国要括立た準。

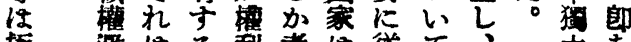

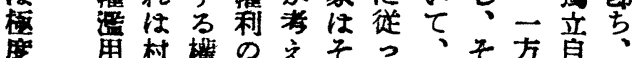

に性落利根られでれに治国

秙以をの庭れに、五ら拢家

の私にのひて模の。 工有ま土維 世地た地持了の

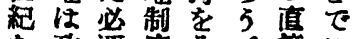
を政要度々。就は 除府々のの安的

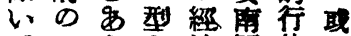

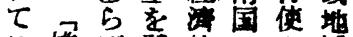
は嫽ば發的のの域

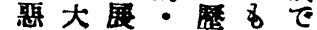

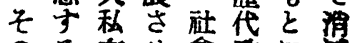
のる有せ雷政に港 得各地了的府再 L らのにた政は與つ れட㩰め策、さ たて政にの五れる 結子惜支百る万 果つろし配年の公 はたこげ的近を奋 む。它基々見加

ししさな調にる。 


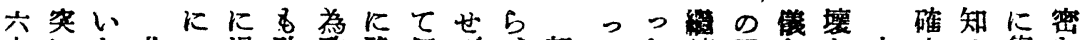

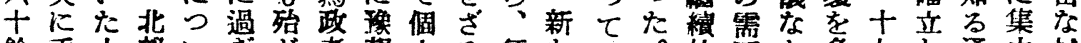
餘手士部いきと者想人る征た认。的要か触九通中村 年を势にてな存の外にを服なた国でをら出世てりし落

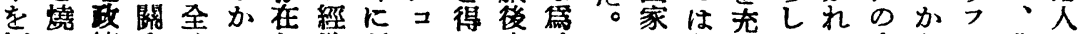

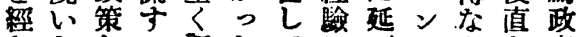
たたとる琶たてはびセか方者 今䊅は限識かい、てッっにた 日果異り不らな安いシた起ち にでる、足、か南た、の起 至あ臤フで公っのかンはた るる策ラあ男た領らと賞フの まとをンっが交土、し然ラよ

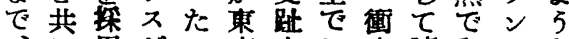
、用がの京支は突讓恋不な こ、世直もの䛍㐫は源方の狀

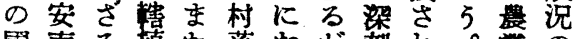
國南る植落ちが刻れ。亲の の傳を民賞生け人な得村椎中 一統得地然活る品子落民へ 般へなととに主をのと運鹙 的のくしい打干艋で信權動込 桱こなてわい有海あぜ利がん 泖のっ領水て餎でっらは村て を屈た有は占年あたれ落來 辰服のしなめのり。た見のた 耕加はてらて行まフ来自權の 段之、そない政たラ耕䛆利で

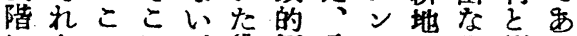
にかのに。役穞厹スのそ衝る

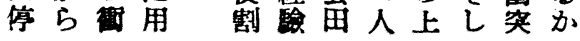
とあ足めて中らラ非口

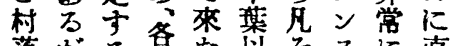
落加万各た以そスに直

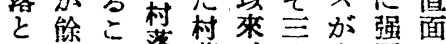
の 等落こ干東国し 接活に裂を年京なた

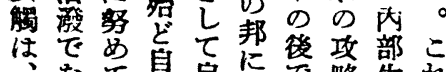
なて給自䋲て略生れ

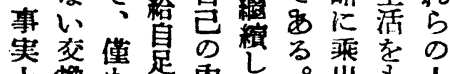

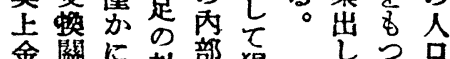

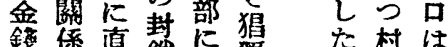

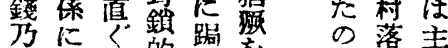

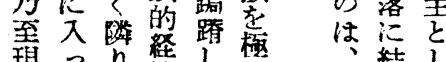

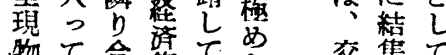
物て合集て生た 交集て

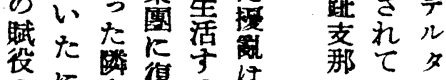
のに人復る住のいの 提過と鼾气侵統た南 供ぎら立略治。部 にな間自を学権人筧

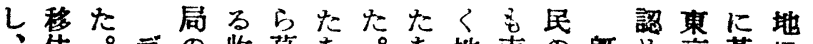

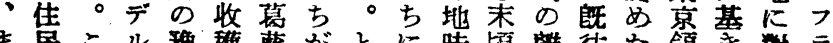

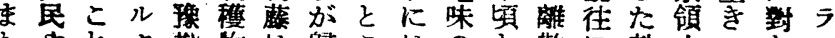
たやれ夕期物は㱆こはのと散に勅土一しン

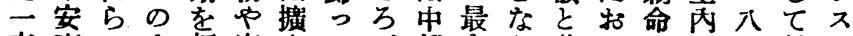
方南の人超家大てか部多り共いをに父熱の

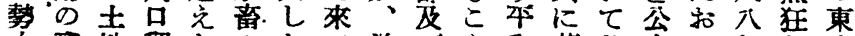
力高地稒たのたて治び和㐬此布い年し京 あ官て密8破。再安高たが陵國してそた領 るははなの壤行ひの地土確にのたつの有

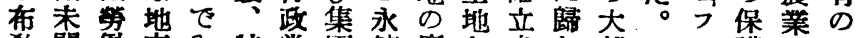

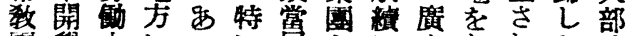
團秏力にっに局をに大われた分 はののあたまに結勇なれるさを 自米聕る。た向集楊面さに地荒

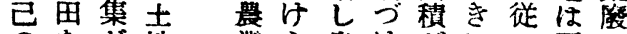
のを地業ら自けがにっ再に

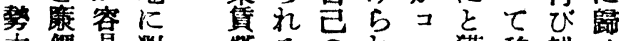

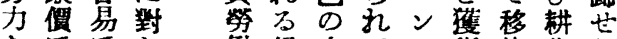
をでし 酎器力て七得住作し

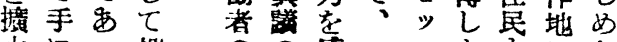
大につ投のの病一シよをにた し入た機能坦知時曰5村復匪

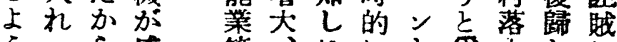
5 る 盛等、はにと争名しは とこ、ん移じ睢しっ位た制

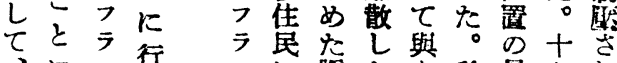

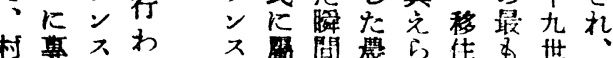

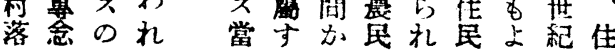

ラ護大一 之国植入 石王元

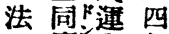
に杯趿 年 從帝离がか つは行 5 て市わ一 ᄂ民れ九 不及たり 佛フ年 を國ラの 所保次面 有蛲不主 于民政它 万に付 権路の末 利 ᄂ 勤開 を告犁
間负潜 題层世 と な 乙。

L

遗て住

子小民

乞た衆

r

令保

た日寸

の の ヘ

で篇き

あ政食

る者粞

最間

己 題

过

に

ᄂ 安

七南

ま統

た治

餐 者

拈

たき 
た習と年こしシれるにてン律れ以を長すのか集

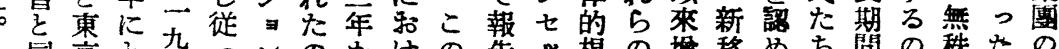
同京之九っンの加けの告》根の堽移めち間の秩たの

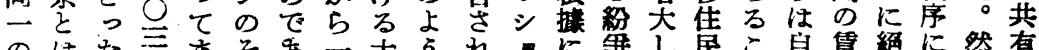

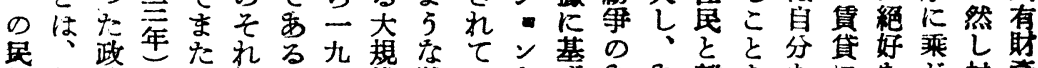

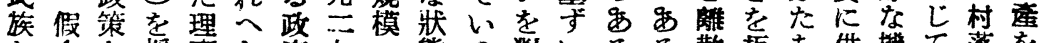
と合を探事を府九子態る對いるる散捪ち供機て落を が共踏用長政は年ンで。侉たす場後絶がせ曾利の差 もに褧し官策大へ七あ解の合再し不らて得長押

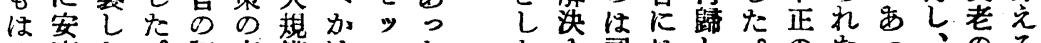

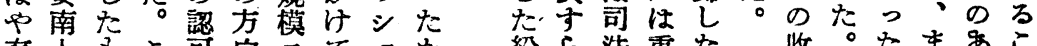
存人をこ可向コて、出紛ら法重た。收。たますこ 在居ののがをン、ンら爭满裁大費・竍村。たると

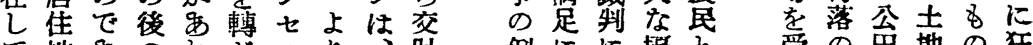

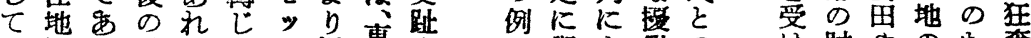

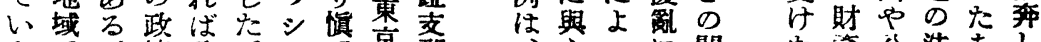

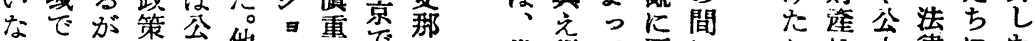

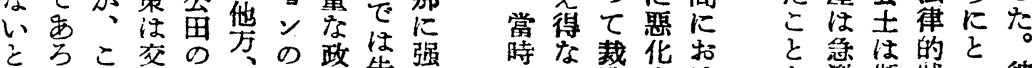
以5 5 趾瀷村附策失行

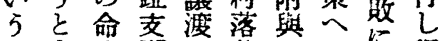
こ命郡を共茄のに得 之起記㑇同ら轉絡た をこ草敌め体尔換り上 理に者いるの規を政 5 解法けて權模餘府な し同交一い利コ㢳は農 な一趾公5をンな一羓 かの支九法制七く九植 つ㥧郡三合限义さ○民民

時な载化お の势淤 政たれ危る

治。た險蛰 的ゴが禁任 なル、ら

危官確手二

機、乎口八 ルたた九

乙二法こ年 至激斯牀っ彼 知にく態て等

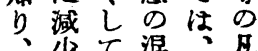
新し売篟賞て 占一却に時肪 有方さ乘の琴 者贫记し村意 の困、て落で 辢なま投行は 利譬た機政な

$D し$ 別降つ5局ろのもの

は至地い多入地へ極せ生

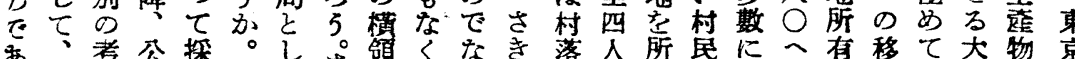

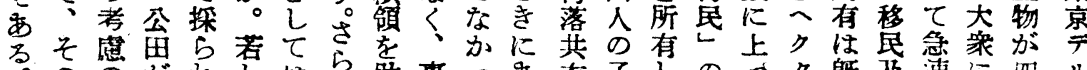

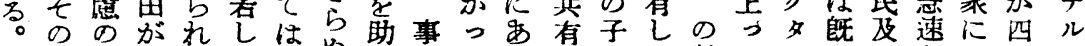
保對再る公は如長售たげ地供な数て、にでな勞百夕

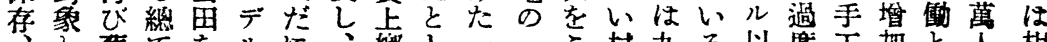

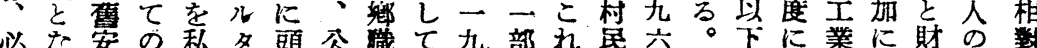

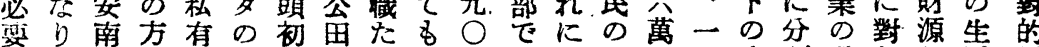

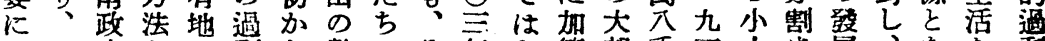
応デ府をに剩ら數にそ年な算部干三士さ展、省耤 じルの無轉人こ、やよれの市し分人元地れはデ保㱠人

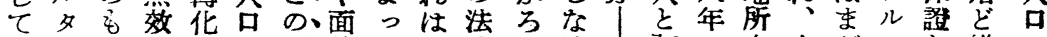

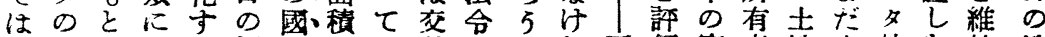
そ人にすれ捌の、を本趾は加更價官者地充外な持地 の台就るばけ、減常索 撗政けで、口、業少犯那村 張策る要投妾化世さに落 热よら機何をしれ括共 さむ 55 㤎處阻めてい有 光しに。筧に止るいて地 企万公々麻求し、結たその 㘣救權こなめて、果村の廃 さ賁力で住た來、落先止 れ政の一民らた招共例を る策側九のよフ來有を意

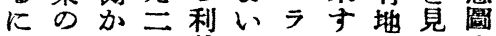
至一ら九盆でンるのるす つつの年をあスて不まる たと特以訪方當西法です ばにさ聽で所分部け出带 な一れ統あ有なまれ來 ら人て部る都效たばな な當いに。の榡はないて いりるよ土九索印ら士有 华市地三痕度な地名 均そばを\%芰いでで の一し子奪はし辫。六西

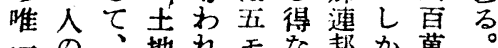
一の、地れモな邦か萬 の妻こをたウかのる人 生之视住即っ他に餘こ

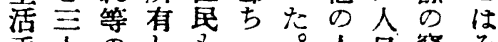
手全のし安一古筑 
さ吉なででルよれこ同は放使えかの動

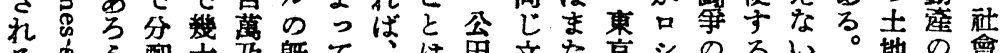

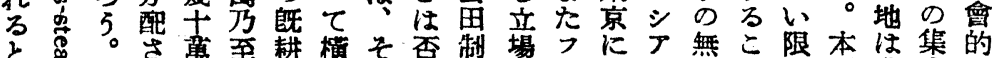

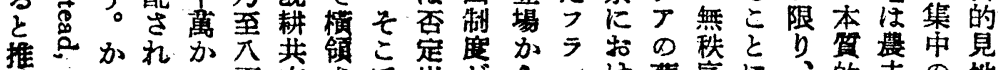

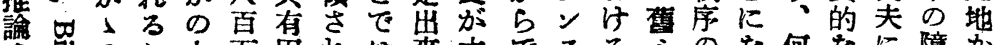

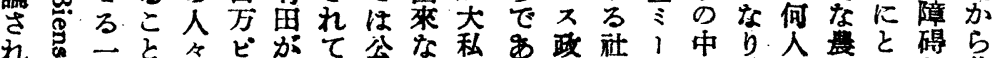

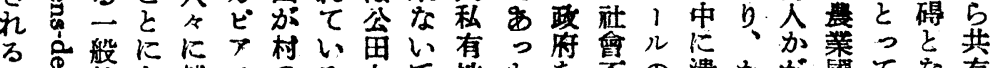

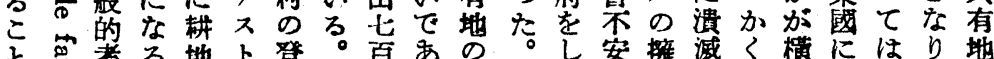

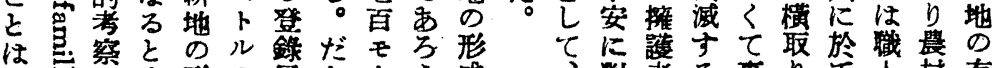

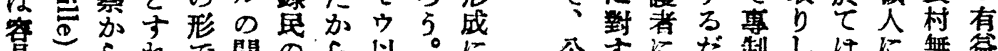

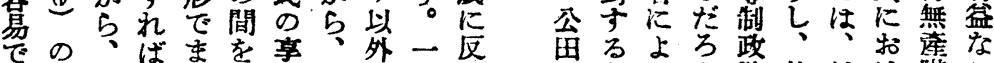

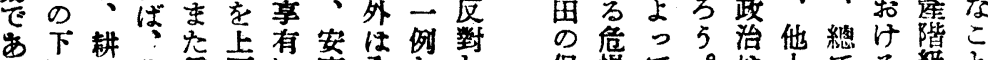

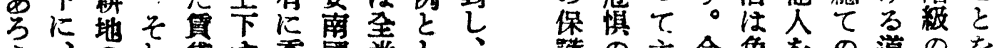
万。不のれ貸子委國米し 不一㤝るね田て 可部素上額 5 拉大很

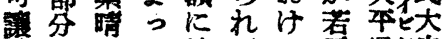
渡がらて達るる装棌 の例し引しと三の堅に

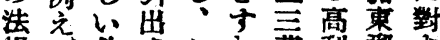
規枚さこれ萬利郡子 に家霓れれば五貸のる

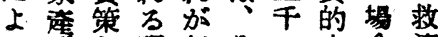
つ形主現华々一大合济 て態な金なれ》地をと 維兮るの雉は夕主あな 持宁它形保四、に代る

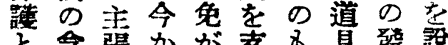

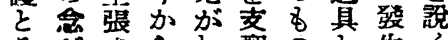
そがさら和配のと生く の總れ六得子に闹をる 助てた十なる土樣妨の 長の。年くた地にげは へ薄な前なめ必る、 透安にりに享要、士 以南气衣有なと地 た政 の街の權勞いの

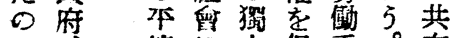
は等は占保手。有

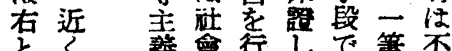

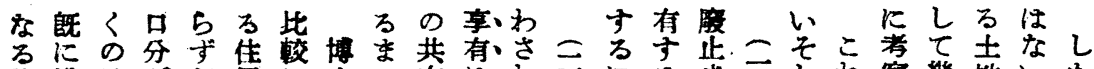

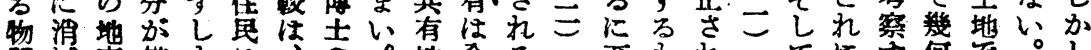

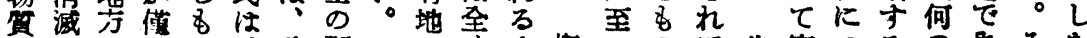

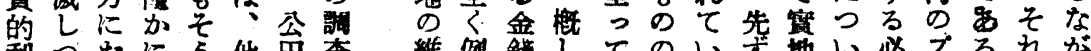

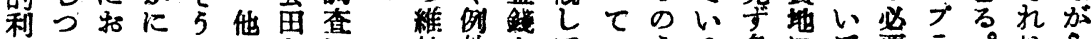

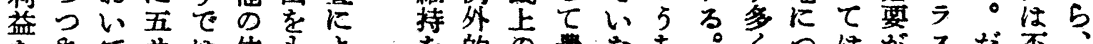

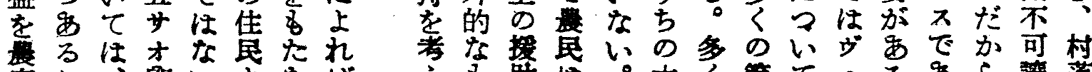

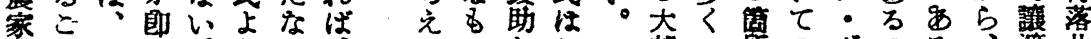

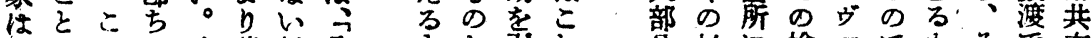

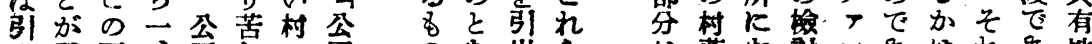

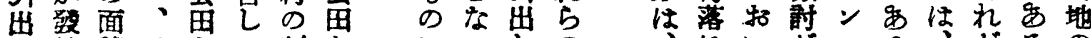

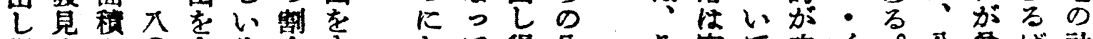

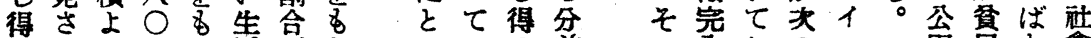

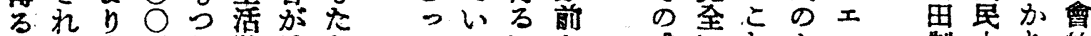

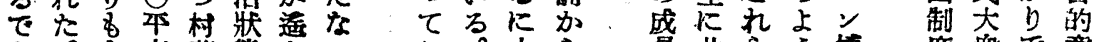

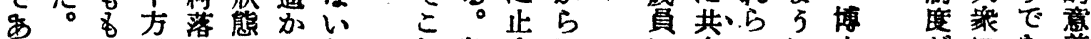

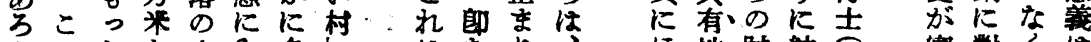

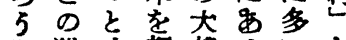
方猫尔超部方以と

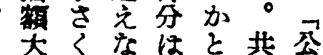
大くな采基忩 土たのそ充を䒚 地定及の代知 加期な一 注方 号 意社直、る な佥接、䝿

耛 年 耕、帒

果 和 作、假

そのに、格 号的 5 人事な村 い要よりに わ具るよ ねと現了

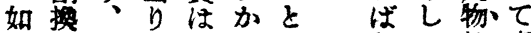
何は多の必加の

ほ地財結文 んを济論气 の衰管し文 嚾失理て

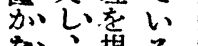

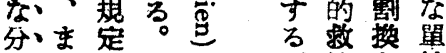
前た守の面済を純 し之る最を党な

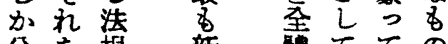
分を規新體てての 配保驾し的果いで 
る 要になのて

たたと時尔收らと め的折规權れす

にらて從模はたれ

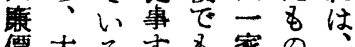

價大るす家の

て部のる、劣は大

口分てた一支、梅

分の市め定充直二

公公にのる接登

覒画。水に耕錄

貸の

ᄂ享の号に当

或䀂場維な從 口

は者洔心事五

見它家宁。广

越る族害而る才

筫登の草をこを

入錄一の远

す导人除赥は方

る付去作不名

の、至等は可こ

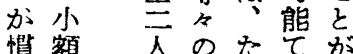

わの加細とあな

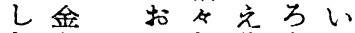

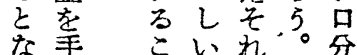

りにと手茫一交

入圭入と口船

地れ必れ九行虽
あ毛が作培京全た仕親家に作四 る作、をに地家こめ事は搠よ子人一 のそ普お方族のにの田のっるよ九

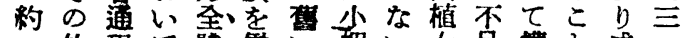

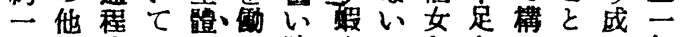

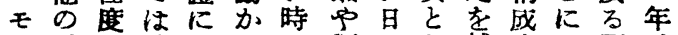

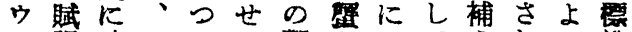
の課確三いる觀をはて5れっ準イ 米は保公てこ祭䱶、村たてて家ウ” 田免しで云々はり彼のめい、族・ か除得一える、に女地にるそがて らさろへる充一ゆ住は|の一ン のれとりこ分モ少子の、臨モり 收て評夕とでウ放供家口を要ウ!

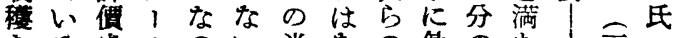

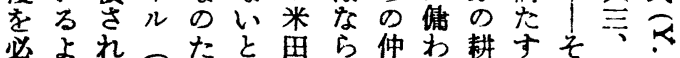
要 5 七ほ。いの間れ作にの六工

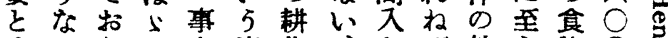

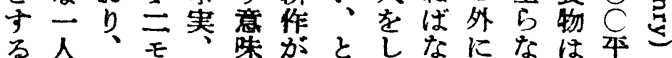
る人、正味がとしなになは本こ との村ウ手に戠福父い各方は 看者落入の於家い微な親、棰米南 做をのサ行它をこ細いはとの定

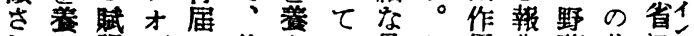

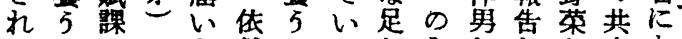
てにはのた然こるしるとしを有お いは負米士とと。前なして鼠米い る、擔田着し\&岳ていし田て

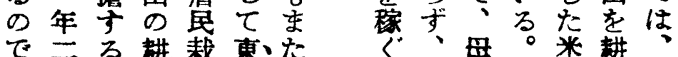

あな

万若

50 ᄂ

之, 公

印了制

度て度

考いの

郡万留

にと䤑

括尔肪

けれ前

公は記

思 ᄀ

制ラヴ

はスン

今政・

日策

その工

の意ン

存㘣 博

在す士

のろの

意と指

耊学摘

失がる

$\begin{array}{lll}3 & \text { cै } & 5 \\ \text { 七 } & 5 & 5\end{array}$

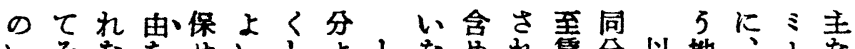
いそなをせいしょしなめ犯貸分以地、1た くのい保し。鸟加いる袋前上主果儿ち ば形。持めこは引しのので者のに京にの

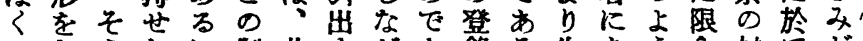

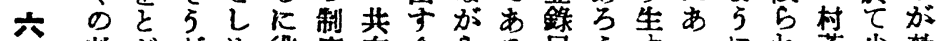
効どため役度有金らる民 5 专っにれ落少妁

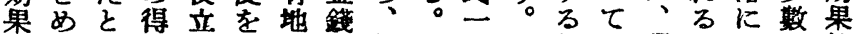

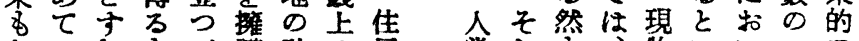
あいれすへ護社の民民當しも物いいつに げるばのま等會援が界年共厄

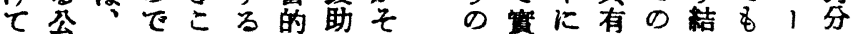

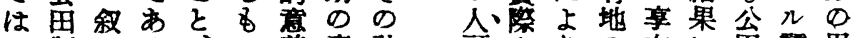

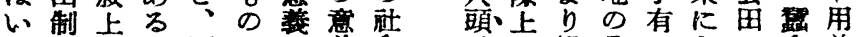
な度のこ而には義會秷は場分はなの食益 Wが暂としとそが的を何所前例口面者權 こ態にてっのと負專虎に上外て值にを

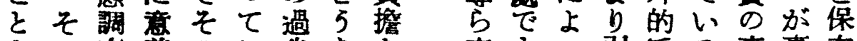
をの查意のは坐あを支るつ引でる事事有

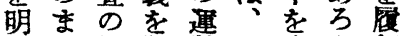

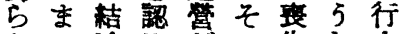
かて論め外の失と先

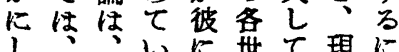

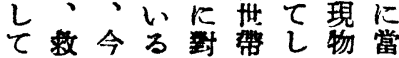
い費日こしにをにこ ?政安とて不 5 よて 策南は摆、動とる 々に立音い事々

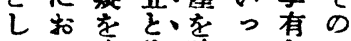
てい客自確てな口
辩品出あ。夋笽守 す分異れる者上る るのるると㤨に こ貨一援しし有過 之僧定助て は地き に料皟はすしを求 しがの 加金飞大 役附錢の多 立加に留 数 号模換入の 七孝策乃共
は橫 利 $L$ シ 倛た 行亲占 高領口 


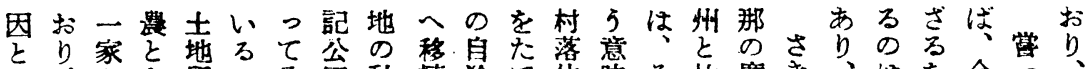

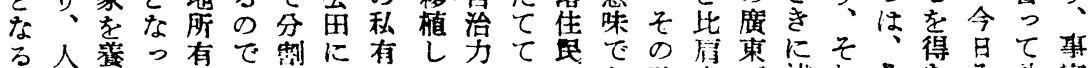

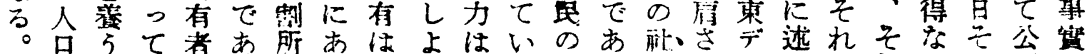
だの限いのる有て行 5 侮る㱠る命れ几べがれいの田上

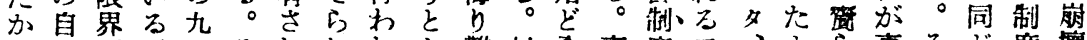

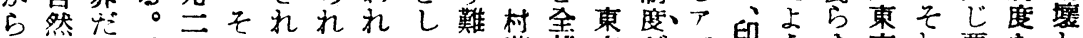

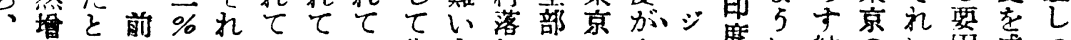
さ加す記まはいいお失子組にに人、ア度に結のに因成つ

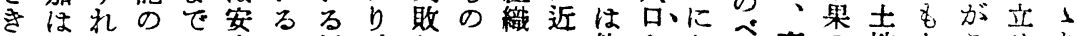
に、ばよが南の以、しではい約をお文東の地かこせあ

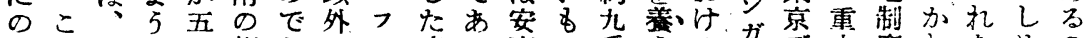
ベれ土にモ相あのラ史る南の千5、る沓だ大度わをめの

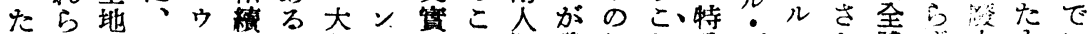

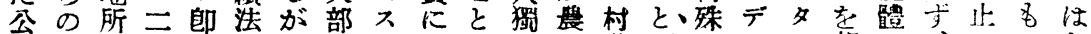
画土有玉ちに、分のよは特莱落がの礼は想の、ののな

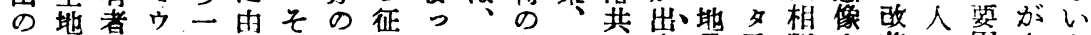

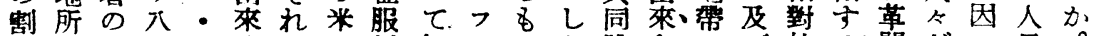
賞有大サ元守田以知ラのか體なでび的る゙問がへ口。

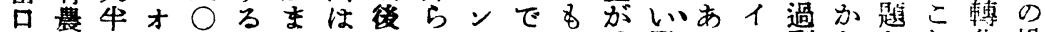

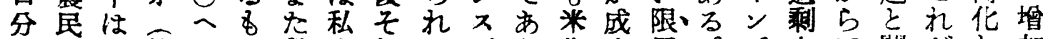
がのこ約クの箵有れるがり作立界。ド人で閶がし加

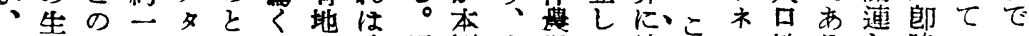

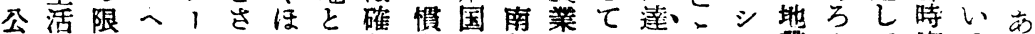

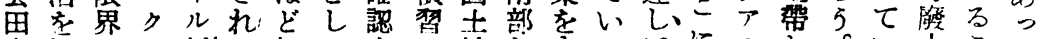

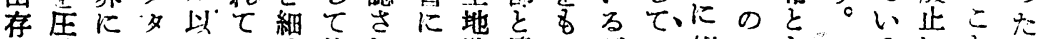

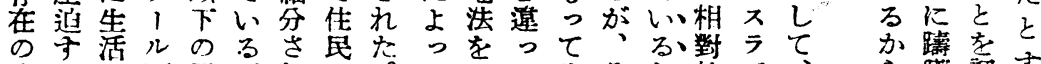

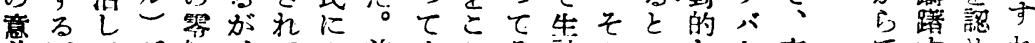
義要てが細、てょ前土こそ計のいとな支ですめれ

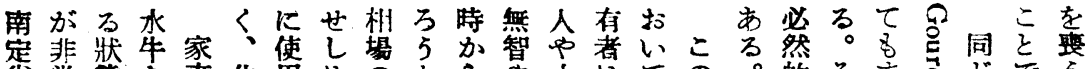

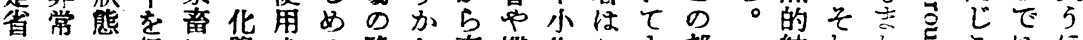

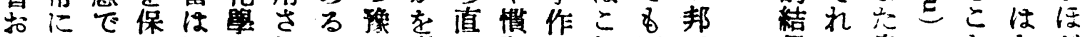
よ郴は有國肥れの期考方習人れ同で果に自のをなと び蜼家子の料てでしえにめに等様ははで確はくに 太で畜る全はいあなる得充委のにに拘の䓂そて

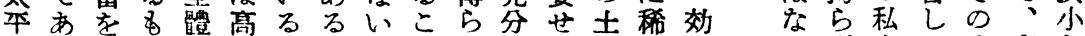
省るすのを僄。戀とれなて地で果 沉なは通なし自動がる資满をあが 打な非忌た加給出出幾本足小る長 いでい常てめし肥到來らをし士。期

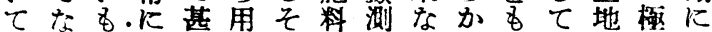
はけの裕だいのといのたい所め瓦 れに䋹稀ら奻、加。收なる有てっ

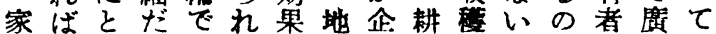
蓄不っとあるは方䨢作のとでとい永 の可ているこ何にと啳こあ同面綘 數能は5。と年よかのにら、り樣積子 はで適こ何はるっい偶はか店はる 全あ時と處例つて 5 然どら小方士ょ 米るにがで外ら゙多精の5 彼士法地 5 田之そいるでく少嘞出い等地でにな

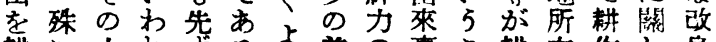
耕に土れ娄る美の事こ耕有作し良 寸地て二。5 はす中作者す七は

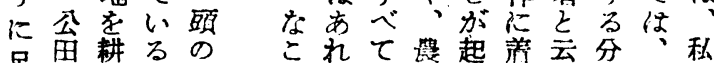

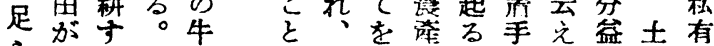
ら多こか乃海埧物でし代小地地 ないと小至市基衰のあた作所に

くす有て生果な 生地 東恡にる力のの 京力おとに私で にがけこつ有あ お低るろい地っ けいとにたに

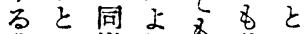
㖘い樣れ共い 業 5 な心文通 5 湾之遭農方ると 般は、尼 $\mathrm{P}$ 現は にこ䑤共がなな

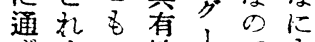
ずまつ地市です

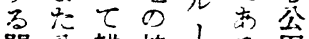
間公耕持速畐 题田作分留。に な制しに士 限 の度て 拉 


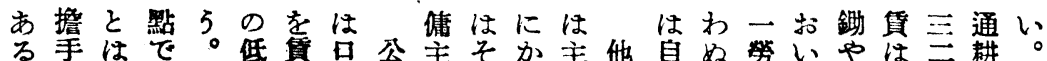

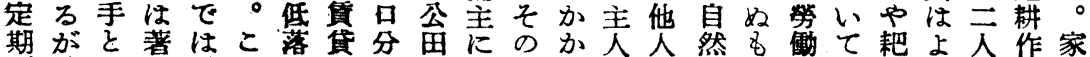
割確しし早のをし田の對共わとののの梳をりにを畜

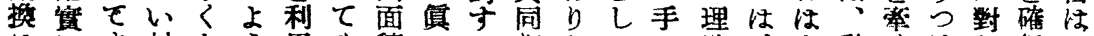
はにま対加5用や積のる契なてに法、人動くけし保こ 無伸た矿らなしがが受の約くとそと公間物のなてしれ 秩ひ公をつ地てて僅益と者、どのい出ののをい二得ら 序て畐なラ主そは少者同た經ま權わを三借息ほ頭るの ない制しンはれ舞ではじる濟っ利ね貿乃買受どのと地 排る度てス、を產々勞從貨的てをば入至をけ高牛䛨方

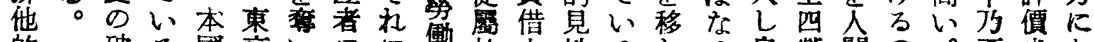
的破る國京いにに謿的人地るしる自勞間の。至さ扰

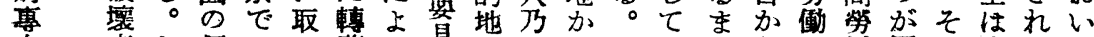

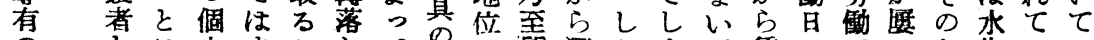

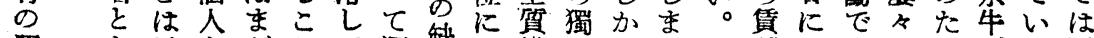

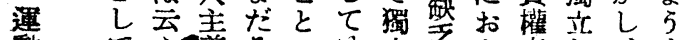

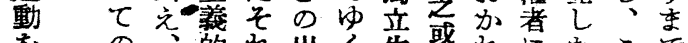
孛の的れ出人生或れたたこ艺 終大東士ほ來す活はる。對生のは 結、地京地どるのを運のし活法 さ主に法变高で營轉で、孝律公

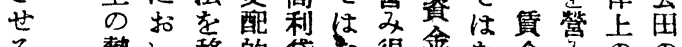
る勢い移的貸な得金な金学のの た力て人で的くな不い勞得ヴ受

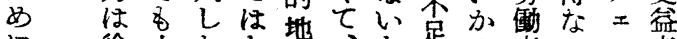
に徐土たな主たた足? 者い, 者

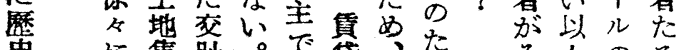
史に集趾。で貸、た场

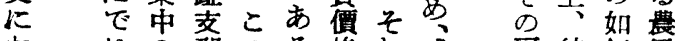
打はの那のろ格れ或勧彼何民 働っ掼あ人存に均 者て 打る間子斿し 之支 50 㤎及拘七 し拂とこ三にら三 七努れ、過ず

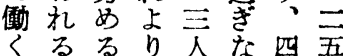
道。惠でい、へ を学郎を動。クク 選机方机物従夕夕 ぶ物、たのつ1 。乙水管代てルル こ名牛區り耕及の れ能のにに作び普

は亞會れに課た こ細政に打題最㰷 れ卧策閏けと各記 に上時連るし重記 着第報守土て要 手五しる地そな戰 守卷第も制の問後 る第三の度研題に こ 三と究はお と號五しう成士い 加乙號て南果地て 出等言洋を間 來妾印佛經發題了 な発印領濟表でジ か表葍印研しあア ○那度究、るの

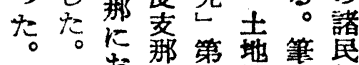
昭し括の六間者族 和加人矮題は古 十七、吕第に践賞 六、躄及四口前面 年公氐躆い印 ᄂ 印画生食七度 度制生樶を支支心 素度活間發了那る 那に永题表印の共 へつ帒上し、度間通 渡い气ラ、变題の 航て新社そ那をま
よいおななははにも族る定姴い

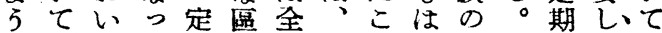
な子てて期別般飞れ中全各割なあ 時總はい的でののを何勞家換いら 代じそる剿は利構貢人働族を限わ はてれと換な谷战貸か力に必的 既農はこはいに貝すらを毁要にた

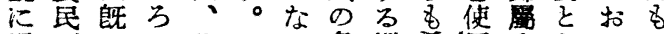
過がにの々 る负㤨希解守しいの

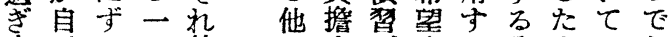

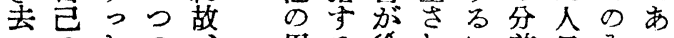
$\supset$ ๖ の、 て 口以麼自 以分前史然 尚田加的の ○ら範 成 自消 漀行 立隇にに 的し過よ 二經て ぎっ

九營しなて

九空まい既

无 态。に

- 分て交㲚

- ない些減

○基る卖す

三学暻村。 出に落のの 守拉にと
用万徐れに能古2。 途租々なるがの存た に稅にい2之增續し 當の作。たの加し思 七一ら總な家が得か

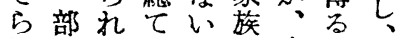
れのるの場を今にそ る卖。分合呩日過れ か拂共前に5でぎは とに同をはにはな㖘、 い使娟結、更々心羓、 5 用加合現足れ。技、 こさかし物らを他術、

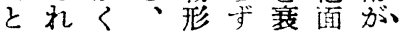
はるし共態ま䫋ま根 せ加间它たさた本、

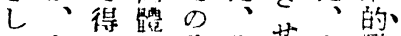
てあたの分之せか變。 雷る金晸配のてつ革、 奖い䤦めは家いてを、 

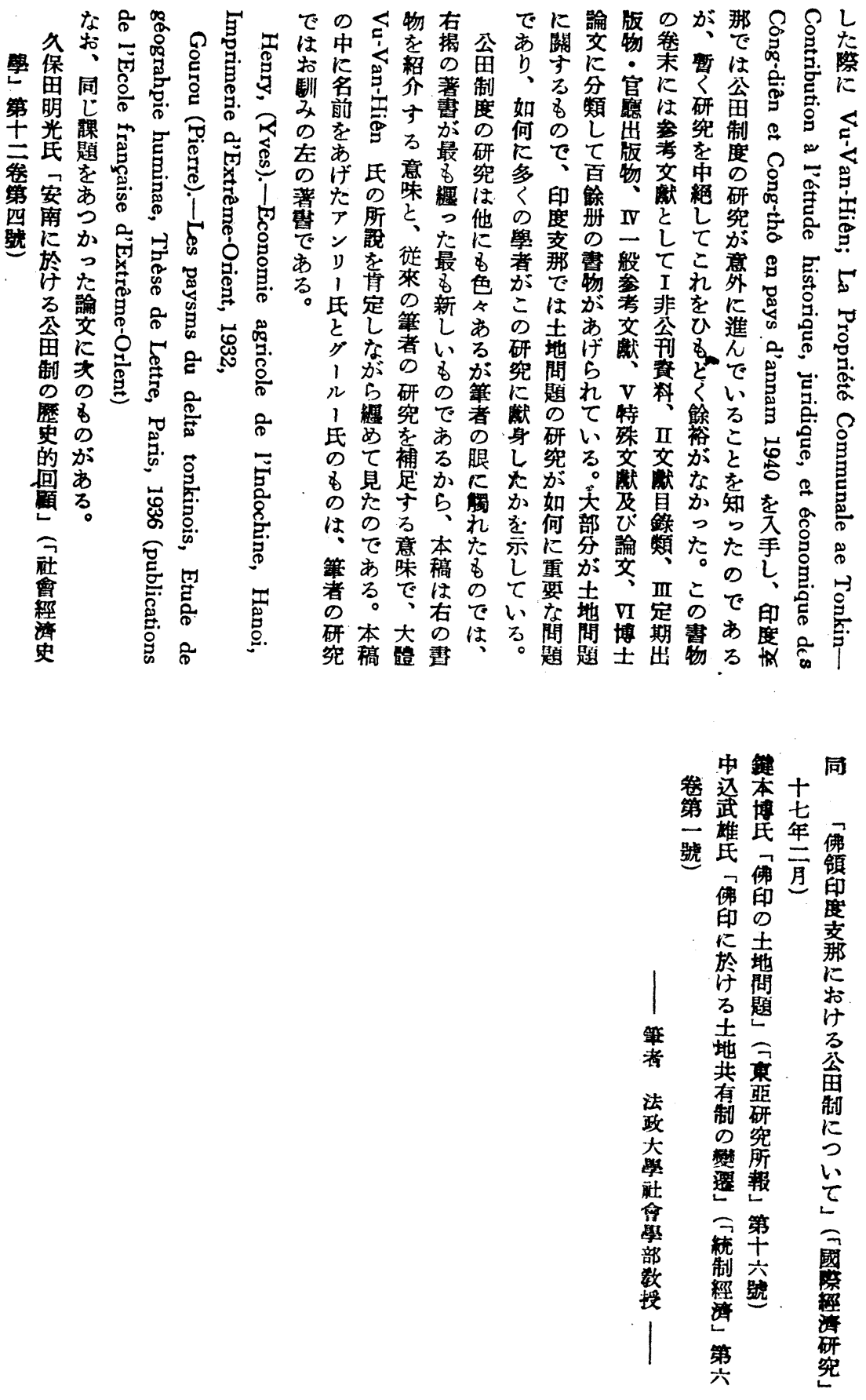
Empirical Measurement of Human Relations in Industry

Mikio Saegusa

The problem of human relations in industry considered here is principally that of the intensity of interpersonal relations in the work place. A tentative plan is suggested for a method of measuring these relations, and is examined for its methodological significance by comparison with sociometry and the social distance measurement.

\section{The Clique of the Feudal Clans}

\section{Sogoro Tanaka}

In the consolidation of the modern state, advanced sections of the community often lead ocher, less-advanced ones and sometimes enforce consolidation by conquest. In Japan, the four feudal clans of Satsuma, Choshu, Tosa and Higo formed a state through a secure consolidation with the emperor system, and thus brought into being a nation ruled by a feudal clique.

\section{Communal Property in Indo-China}

\section{Shigeo Henmi}

In South-eastern Asia the Annamites have a unique "Communal Property System" (village commanal land). This is not a relic of an originally communistic system, but was developed to cope with the population problem. The later increase of population made this system meaningless, but it continued to persist even after Annam became a French possession because they left the country economically retarded. This system will suffer the same fate as the "Mir" of Tsarist Russia and disappear with economic development.

\section{The Extended Family Group of the Honganji Temple of the Shinshu Sect at the End of the Medieval Period}

Kiyomi Morioka

Buddhist priest, as a general rule, had to live a single life, but in the Shinshu sect marriage is allowed them. Accordingly, temples have tended to be inherited by the sons of priests, and it is difficult to distinguish the social organization of the temple and that of the family. Such individual families very frequently are part of an extended family group. An outstanding example was the "Ikkeshu", the extended family group of the Honganji, one of the main temples of the Shinshu sect.

\section{Premises for Detection of Feudal Remmants in the Family \\ Shuhei Yamamuro}

This paper is a critique of Prof. Tadashi Fuhutake's article on the family appearing in the recent publication "Feudal Remmants" edited by the Jimbun Kagaku Kai. The criticisms are: 1) MacIver's conception of the family, which Prof. Fukutaka uses, is ambigous and unclear, and Prof. Fukutake's interpretation of MacIver's ideas is believed to be open to discussion. 2) It is possible to consider that change in the family lags behind that in other institutions, a phenomenon seen even in American and European societies. The source of this lag is related to the fundamental nature of the family.

\section{The Structure of Fishing Communities and Types of Fishermen in Japan}

Eiichi Yamaoka

Fishing communities are generally more backward than agricultural com. munities. This feature seems to drive from natural conditions and from the high degree of intermarriage within 